\title{
$\mathrm{SiC}$ 粒子強化 A2024-T6 複合材料の疲労および フレッティング疲労特性解析
}

\author{
丸山典夫角田方衛 中沢興三
}

金属材料技術研究所筑波支所

J. Japan Inst. Metals, Vol. 57, No. 11 (1993), pp. 1268-1274

\section{Fatigue and Fretting Fatigue Behaviors of A2024-T6 Composite Materials Reinforced with 20 vol\%SiC Particles}

\author{
Norio Maruyama, Masae Sumita and Kouzou Nakazawa
}

National Research Institute for Metals, Tsukuba

\begin{abstract}
A study has been made of the role of silicon carbide ( $\mathrm{SiC}$ ) particles in the fatigue strength and fretting fatigue strength at high cycles using powder metallurgy 2024-T6 Al metal matrix composites reinforced with $20 \mathrm{vol} \%$. $\mathrm{SiC}$ particles with the mean sizes of 2 and $16 \mu \mathrm{m}$. The $10^{7}$ cycles plain fatigue strengths of the composites were within the values estimated on the basis of the change of the elastic modulus and the ultimate tensile strength due to the reinforcement. The $10^{7}$ cycles fretting fatigue strengths in the composites were about $30 \%$ higher than those estimated. This suggested that the increase in fretting fatigue strength in the composites was probably due to low stress concentration at the fretted area and crack growth resistance caused by avoiding the $\mathrm{SiC}$ particles at low stress intensities.
\end{abstract}

(Received May 31, 1993)

Keywords: metal matrix composite, SiC particle, fatigue, fretting fatigue, role of reinforcement phase

\section{I. 緒言}

粒子強化 $\mathrm{A} 1$ 合金基複合材料はマトリックスの材料(以後非 強化材料と呼ぶ) 飞比べて, 一般に延性, 靶性に劣るが, 高比 強度, 高比弾性が期待できるので, 輸送関連構造物用材料とし ての研究開発が進められている．したがって粒子強化 $\mathrm{Al}$ 合金 基複合村料比とって，疲労強度执よびフレッティング疲労強度 がより高いことは極めて重要である。これらに関する研究にお いては，材料学的因子であるマトリックスの問題，界面の問 題, 強化相の問題を峻別し, 強化相に関しては量, 形状, 大き さなどに十分な注意が厸われるべきである。

粒子強化 $\mathrm{Al}$ 合金基複合材料の疲労強度佀関しては，比較的 多くの研究が行われているが(1)-(5)，大部分は強化粒子とさ裂 伝播速度との関係関するもので岁る。李た上記の材料学的因 子に着目した研究は多いとはいえない，との中で強化粒子に関 する系統的な研究はさらに少ない(1)(2)，一方，金属基複合材料 のフレッティング疲労に関する研究はこれまでに注とんど行わ れていない。

前報に括いて，著者らは金属基複合材料比ける疲労強度拝 よびフレッティング疲労強度について, 複合化によるヤング率 (以後 $E$ と呼ぶ) 特よび引張強さ(以後 $\sigma_{\mathrm{B}}$ と呼ぶ) の変化の寄与 分と，それら以外の強化相による強化機構発現に上る寄与分に 分けて評価する方法を提起し， $\mathrm{SiC}$ ウ スカー強化 7075Al 合
金 $\mathrm{T} 6$ 処理材の疲労括よびフレッティング疲労強度を解析し たてそしてこの複合材料に括ける後者の寄与分は，主として複 合化炕よるパット接触部の応力集中の分散效果抗よびき裂発生 阻止効果であることを明らかにした(6).

本報告に括いては，上記のことを考虑して，粒径の異な る 2 種類の $\mathrm{SiC}$ 粒子(以後 $\mathrm{SiC}_{\mathrm{p}}$ と呼ぶ)をそれ艺れ含有する $2024 \mathrm{Al}$ 合金 $\mathrm{T} 6$ 処理材 (以後 2024-T6 合金之呼ぶ) について疲 労拉よびフレッティング疲労試験を行いそれらの強度向上への 效果について解析を行った。

\section{II. 実 験 方 法}

\section{1. 対象材料 \\ （1）複合材料}

平均粒径 $2 \mu \mathrm{m}$ (最大粘径 $5 \mu \mathrm{m}$ ) の $\alpha$ 型 $\mathrm{SiC}$ 粒子と $2024 \mathrm{Al}$ 合 金粉末を混合した後，HIP で固化成形，押出し加工により押 出し温度 $400 \sim 500^{\circ} \mathrm{C}$ 押出し比9.5で $25 \mathrm{~mm} \phi$ の丸棒とし, T6 処理を施した。 $\mathrm{SiC}$ 粒子の体積率山20\%, HIP 条件は $510^{\circ} \mathrm{C}$, $9.8 \times 10^{2} \mathrm{GPa}, 14.4 \mathrm{ks}$ である。この材料を以後 B 複合材料と 呼心.

平均粒径 $16 \mu \mathrm{m}$ (最大粒径 $30 \mu \mathrm{m}$ ) の $\alpha$ 型 $\mathrm{SiC}$ 粒子を $20 \%$ 含 有する複合材料も，B複合材料と同じプロセスで作成した。 こ の複合材料を以後 D 複合材料之呼ぶ. 
Table 1 Mechanical properties of the alloy and composites used.

\begin{tabular}{rl|c|c|c|c|c}
\hline \hline & & $\begin{array}{c}\text { Yield strength } \\
\text { (MPa) }\end{array}$ & $\begin{array}{c}\text { Tensile strength } \\
\text { (MPa) }\end{array}$ & $\begin{array}{c}\text { Elongation } \\
(\%)\end{array}$ & $\begin{array}{c}\text { Hardness } \\
\text { (Hv) }\end{array}$ & $\begin{array}{c}\text { Young's modulus } \\
\text { (MPa) }\end{array}$ \\
\hline $2024-\mathrm{T} 6$ & & 403 & 496 & 8.5 & 151 & 70600 \\
$2 \mu \mathrm{mSiC} / 2024-\mathrm{T} 6$ & (B) & 437 & 586 & 4.7 & 177 & 113000 \\
$16 \mu \mathrm{mSC} / 2024-\mathrm{T} 6$ & (D) & 370 & 458 & 2.8 & 161 & 108000 \\
\hline
\end{tabular}
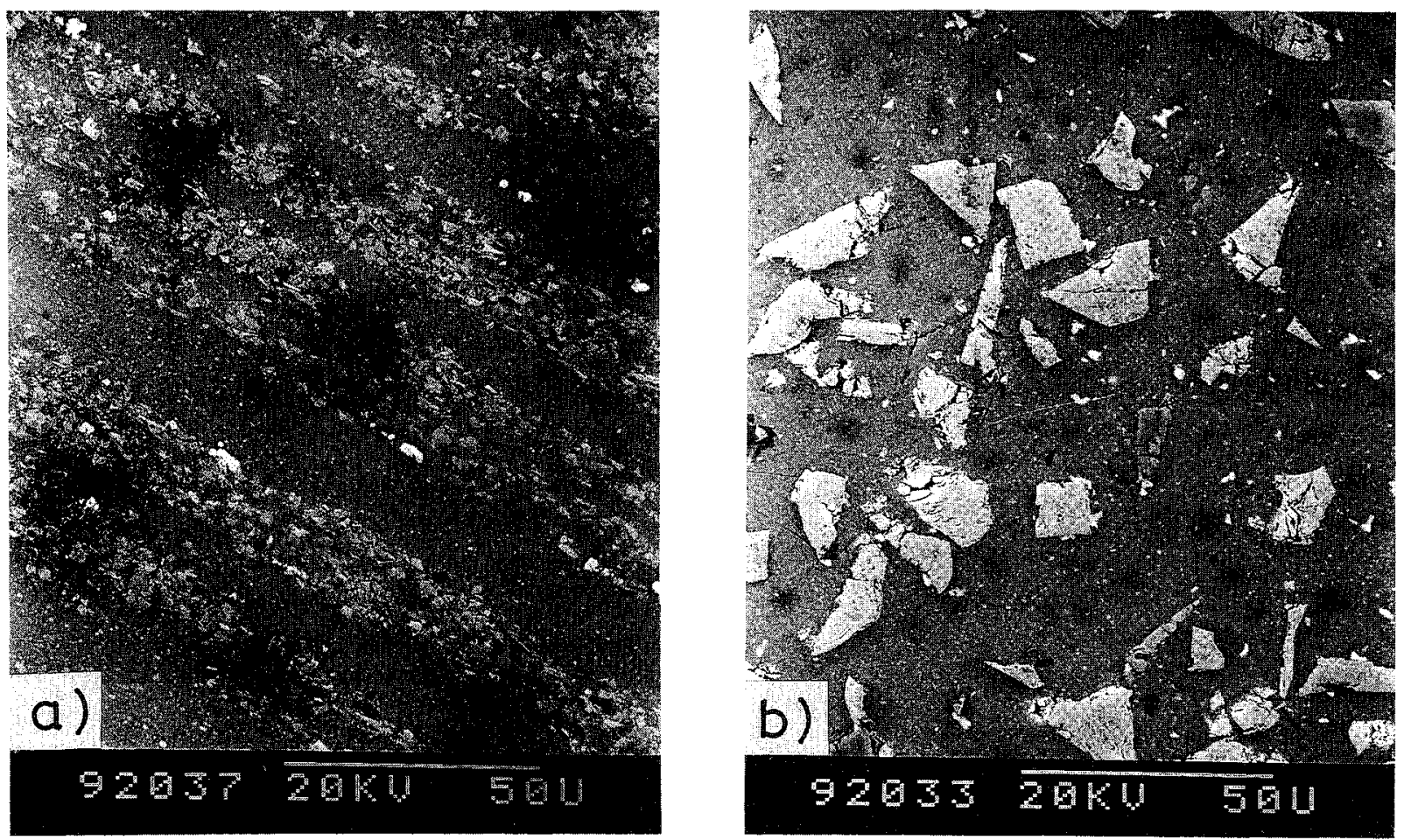

Fig. 1 SEM photographs of 20 vol\% $\mathrm{SiC}_{\mathrm{p}} / 2024-\mathrm{T} 6 \mathrm{Al}$ composites.

(a) fine $\mathrm{SiC}_{\mathrm{p}} / 2024-\mathrm{T} 6$ (Composite $\mathrm{B}$ ).

(b) coarse $\mathrm{SiC}_{\mathrm{p}} / 2024-\mathrm{T} 6$ (Composite $\mathrm{D}$ ).

\section{(2) 比較材料}

複合材料の特性を比較するための材料として市販の 2024$\mathrm{T} 6 \mathrm{Al}$ 合金を用いた。 以後非強化材料と呼ぶ。

各試料の機械的性質を Table 1 亿示す。複合材料 B 括よび DのL方向のSEM 写真を Fig. 1(a) 和よび(b)火示ず.

\section{2. 試験方法}

疲労試験片,フレッティング疲学試験片扣よびパッドの形状 は別報(6)に記したので省略する。試験には土10 t 電気油生型疲 労試験機を用いた。フレッティング疲労試験は, 試験片の平行 部の㑯面にブリッジ型のパッドを一定の力で押付けた状態で， 試験片に繰返し荷重を加える方法を用いた。パッドの押付け力 は試験機本体油压源から分岐した.フレッティング疲労試験の 詳細は別報と同様である(7)。試験片表面招よびパッド接触面は 0 番エメリ一紙で研磨した後，アセトンで脱脂した、試験中に 和けるパッドと試験片間の摩擦力は，パッド中心部側面に貼っ たひずみゲージ上り求めた。

試験は応力比 0.19 軸荷重下で繰返し速度 $20 \mathrm{~Hz}$, 応力波形 サイン波，そしてパッド接触面圧は $50 \mathrm{MPa}$ で行った。試験
環境は相対湿度 $0.5 \%$ 以下の室温大気中で行った。

III. 結 果

\section{1. . 疲労強度およびフレッティング疲労強度}

S-N 曲線を Fig. 2(a) 括よび(b)に示す. $10^{7}$ 回疲労強度は非 強化材料では $135 \mathrm{MPa}, \mathrm{B}$ 複合材料では $145 \mathrm{MPa}$ そして D 複 合材料では $140 \mathrm{MPa}$ であった． S-N 曲線の傾斜部では B 複合 林料の寿命は，他の材料の寿命に比べて多少長い。

非強化材料，B 複合材料怙よび D 複合材料の $10^{7}$ 回フレッ ティング疲労強度はそれでれ $60 \mathrm{MPa}, 90 \mathrm{MPa}$ そして75 $\mathrm{MPa}$ でる。複合材料の $\mathrm{S}-\mathrm{N}$ 曲線の傾斜部の寿命は非強化材 料の寿命に比べて長く, D とBではほぼ同じであった。

\section{2. 中断フレッティング疲労寿命}

疲労寿命に及注すフレッティング損傷の影響を調べるため に，ある繰返し数たけフレッティング疲労試験を行った後，フ レッティング用パッドを取り外し，引き続き同一応力振幅で通 常の疲労試験に移行する寿命試験を行った。用いた応力振幅は 

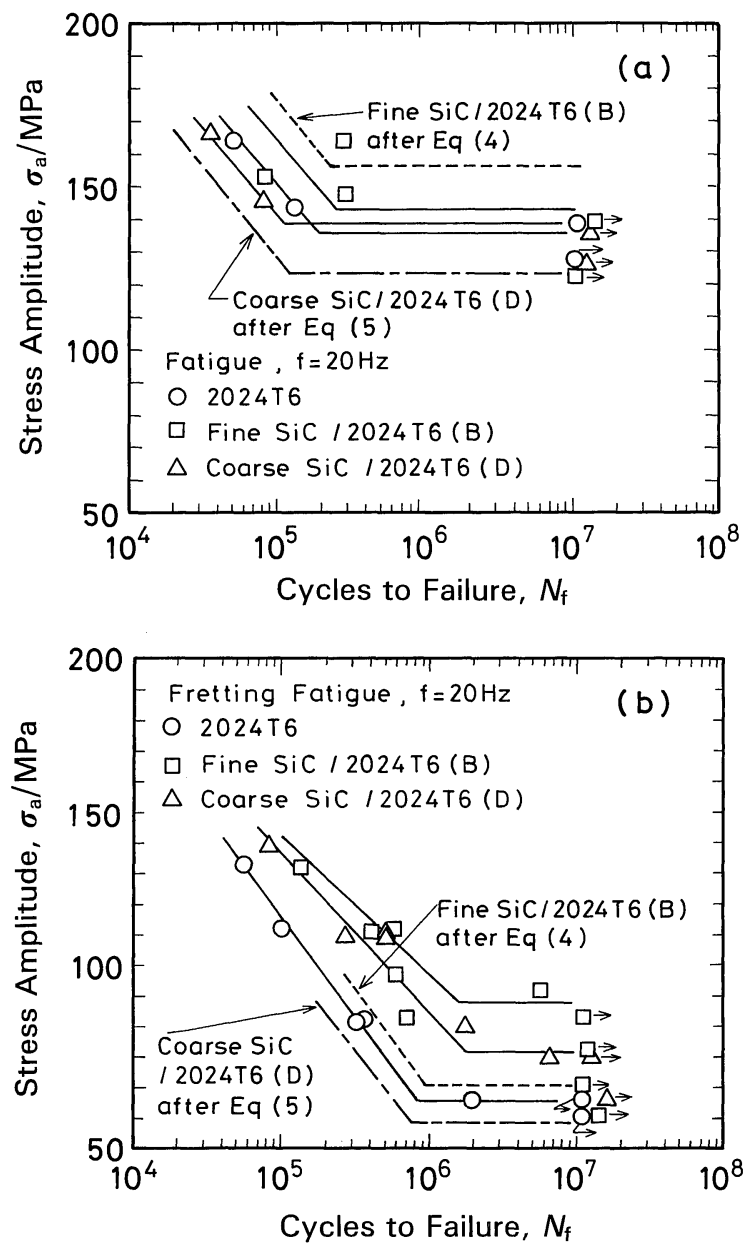

Fig. 2 Plain fatigue (a) and fretting fatigue (b) behavior of $\mathrm{SiC}_{\mathrm{p}} / 2024-\mathrm{T} 6 \mathrm{Al}$ composites and a 2024-T6 Al alloy.

非強化材料では $81 \mathrm{MPa}$, 複合材料では $112 \mathrm{MPa}$ であった. 結果を Fig. 3(a)，(b) 拉よび(c) に示す.これらの応力振幅下 では通常疲労の場合 $10^{7}$ 回までに破断しないが，一方フレッテ ィング疲労の場合 $5 \times 10^{5}$ 回前後で破断する (Fig. 2 参照). 縦 軸はフレッティング疲労繰返し数にその後移行した通常疲労繰 返し数を加えた繰返し数 $\left(N_{\mathrm{t}}\right)$, そして横軸はフレッティング 疲労繰返し数 $\left(N_{\mathrm{f}}\right)$ である. $N_{\mathrm{t}}=N_{\mathrm{f}}$ の線上の值はフレッティン グ疲労試験結果を示す. Fig. 3(a)の非強化材料の場合, $10^{5}$ 回 フレッティング疲労繰返し後, 通常疲労に移行したときの全寿 命は $10^{7}$ 回以上になる。しかし $1.2 \times 10^{5}$ 回フレッティング疲 労繰返し数後, 通常疲労に移行したときの全寿命は $4.1 \times 10^{5}$ 回であり，この值は最初からフレッティング疲労したとさの寿 命に注ぼ等しい.フレッティング損傷はフレッティング疲労寿 命の約 $30 \%$ で飽和する．同様にしてフレッティング損傷は, Fig. 3(b)のB 複合材料の場合約 $50 \%$ で，そして Fig.3 (c)の $\mathrm{D}$ 複合材料の場合は約 $70 \%$ で飽和する。

\section{3. 破面観察}

通常疲労に拈いてき裂発生個所は非強化材料, 複合材料とも に試験片表面からであった。き裂発生個所に欠陥や粒子は特に
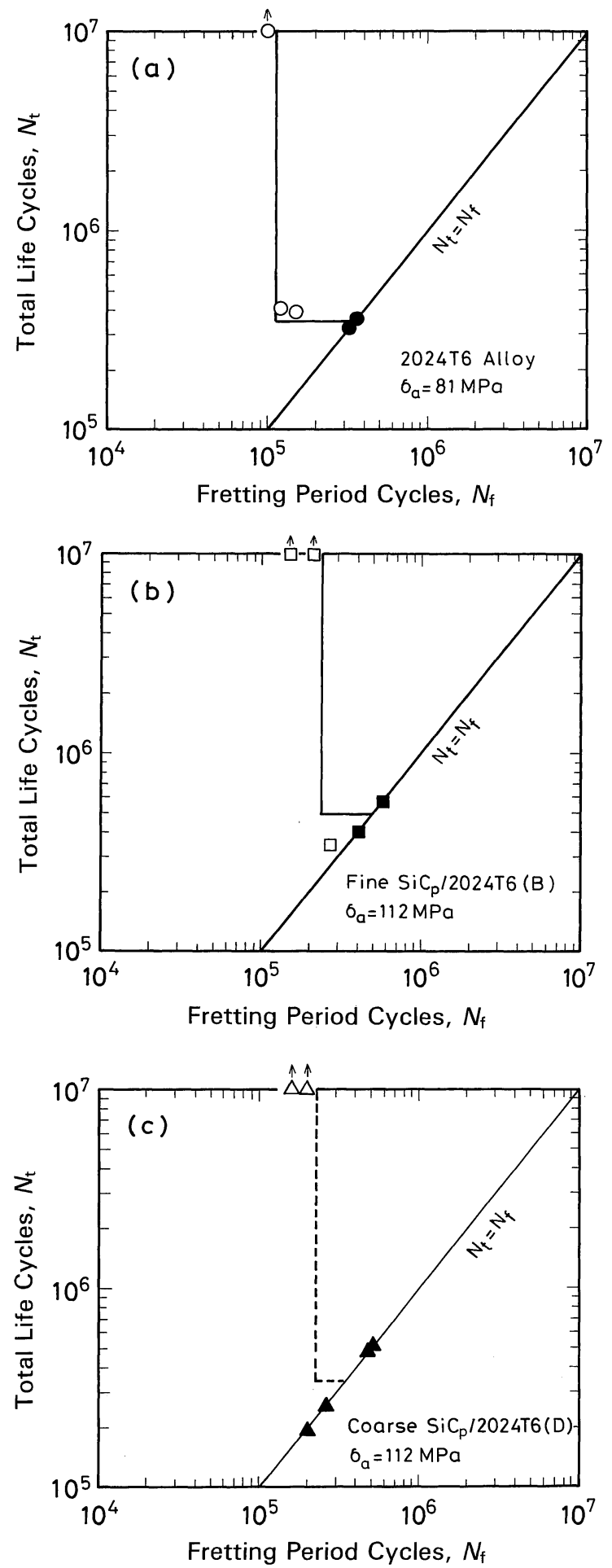

Fig. 3 Effect of fretting period cycles on total life cycles.

(a) 2024-T6 alloy.

(b) fine $\mathrm{SiC}_{\mathrm{p}} / 2024-\mathrm{T} 6$ (Composite $\mathrm{B}$ ).

(c) coarse $\mathrm{SiC}_{\mathrm{p}} / 2024-\mathrm{T} 6$ (Composite $\mathrm{D}$ ).

観察されなかった.フレッティング疲労に执いてもき裂発生個 所は通常疲労の場合と同様であった。き裂発生個所の例を Fig. 4 执よびFig. 5(a) 飞示す. Fig. 4 は非強化材料の通常疲 労下のき裂発生個所である. Fig. $5(\mathrm{a})$ は D 複合材料のフレッ 


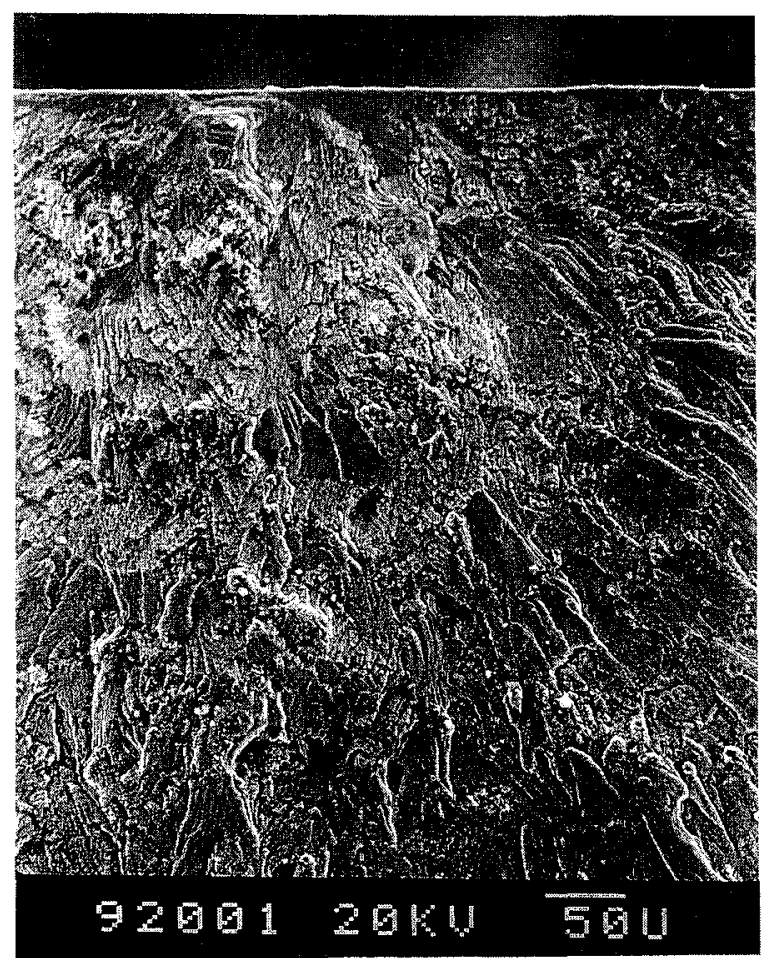

Fig. 4 Typical crack initiation site in fatigue in a 2024-T6 alloy, $\sigma_{\mathrm{a}}=138.6 \mathrm{MPa}, N_{\mathrm{f}}=1.07 \times 10^{7}$.

ティング疲労下のき裂発生個所である。D 複合材料は Fig. 1(b)に示したように平均 $16 \mu \mathrm{m} の \mathrm{SiC}_{\mathrm{p}}$ が20\%入っている.し かしながら Fig. 5(a)に示したように破面上には $\mathrm{SiC}_{\mathrm{p}}$ の存在は 確認できなかった. Fig. 5(b)は裂発生個所から $1 \mathrm{~mm}$ 内側 に入った個所である。ここでも破面上には $\mathrm{SiC}_{\mathrm{p}}$ は忹とんど存 在しない. Fig. 5(c)はき裂発生個所から $4 \mathrm{~mm}$ 内側に入った 個所である. 破面上には多数の $\mathrm{SiC}_{\mathrm{p}}$ が観察される。 $\mathrm{D}$ 複合材 料について, 疲労和よびフレッティング疲労破面上の $\mathrm{SiC}_{\mathrm{p}}$ 面 積率 (以後面積率と呼ぶ) とき裂発生個所からの距離との関係を

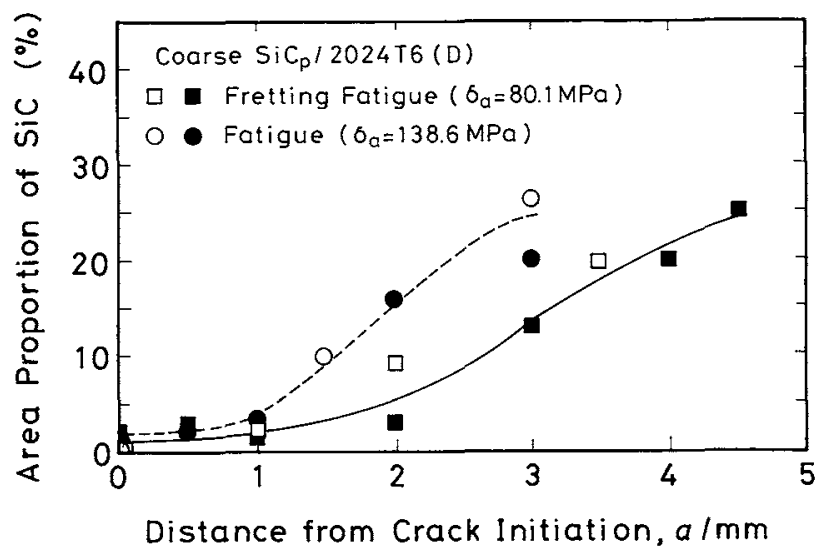

Fig. 6 Area fraction of $\mathrm{SiC}_{\mathrm{p}}$ as a function of distance from crack initiation site for the composites $\mathrm{D}$.

求めそれをFig. 6 亿示す. Fig. 6 中の記号口と口は同一試験 片の二つの破面のそれぞれの測定結果である．記号○とのにつ いても同様である。き裂発生個所近くでは $\mathrm{SiC}_{\mathrm{p}}$ 面積率はぜ口 に近いが，き裂発生個所からの距離が長くなるとともと面積率 は大きくなる，その傾向は応力掁幅化依存し，疲労仙よるき裂 進展領域が広い注ど， $\mathrm{SiC}_{\mathrm{p}}$ 面積率が低い領域は広い，き裂発 生個所から 3-4 mm 離れた個所の $\mathrm{SiC}_{\mathrm{p}}$ 面積率は $\mathrm{SiC}_{\mathrm{p}}$ 体積率よ り大きくなる。

\section{N. 考察}

1. $\mathrm{SiC}_{\mathrm{p}} / 2024-\mathrm{T} 6 \mathrm{Al}$ 複合材料の疲労およびフレッティン グ疲労強度の推定

前報に和いて ${ }^{(6)}$, 複合化による金属材料の疲労強度括よびフ レッティング疲労強度増加の中味を, 複合化によるEの増加 と $\sigma_{\mathrm{B}}$ の增加尔るいは减少に基らく寄与分，とれに強化相に上 る強化機構発現による寄与分に分けて評価する方法を提起し た、その方法とは，式(1)执よび (2)が成立することが前提
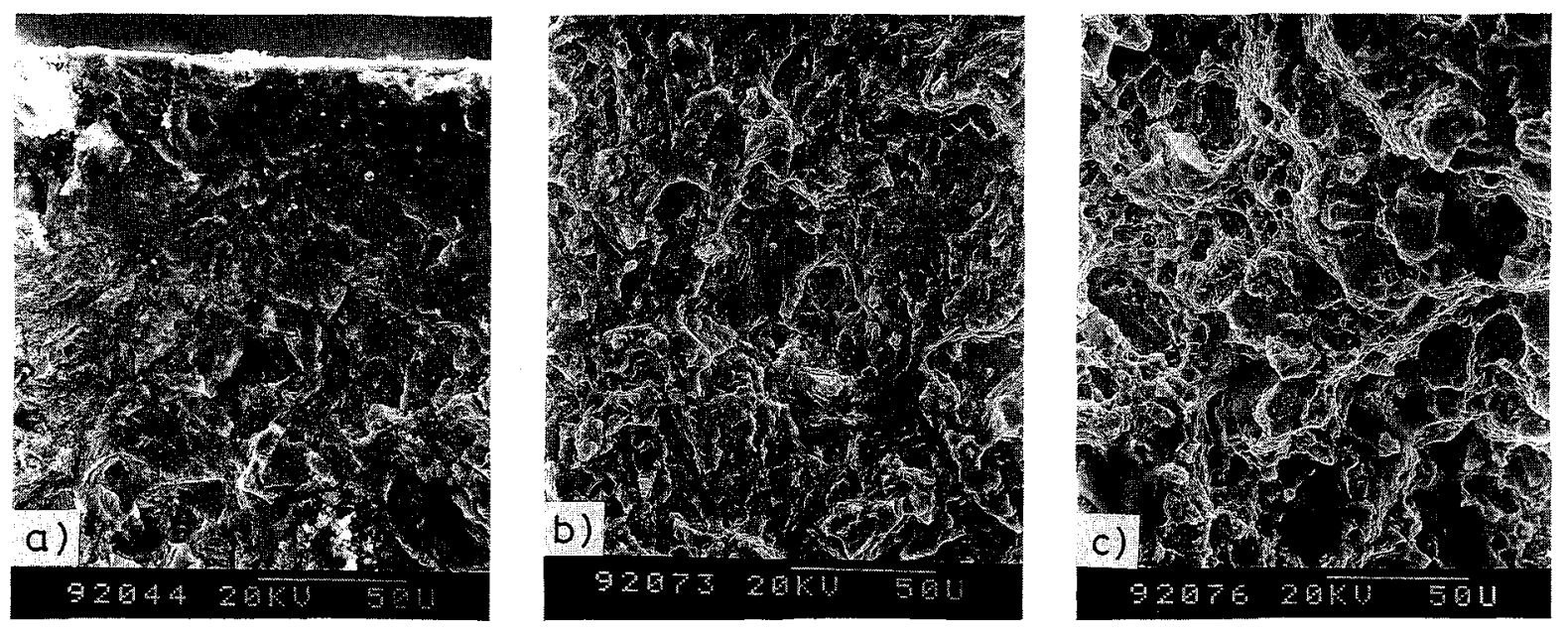

Fig. 5 Fractographs of a coarse $\mathrm{SiC}_{\mathrm{p}} / 2024-\mathrm{T} 6$ (Composites D) in fretting fatigue. $\sigma_{\mathrm{a}}=80.1 \mathrm{MPa}, N_{\mathrm{f}}=1.76 \times 10^{6}$.

(a) Typical crack initiation site, (b) $1 \mathrm{~mm}$ inside from crack initiation site, (c) $4 \mathrm{~mm}$ inside from crack initiation site. 
となっている。

$$
\begin{aligned}
& \sigma_{\mathrm{w}, \mathrm{c}}=\sigma_{\mathrm{w}, \mathrm{M}} \cdot E_{\mathrm{c}} / E_{\mathrm{M}} \\
& \sigma_{\mathrm{w}}=K \sigma_{\mathrm{B}}
\end{aligned}
$$

ここで $\sigma_{\mathrm{w}, \mathrm{c}}$ は複合材料の疲労強度拉よびフレッティング疲労 強度, $\sigma_{\mathrm{w}, \mathrm{M}}$ 㤬非強化材料の疲労強度扣よびフレッティング疲 学強度, $E_{\mathrm{c}}$ 複合材料の $E, E_{\mathrm{M}}$ は非強化材料の $E, \sigma_{\mathrm{w}}$ は疲労 強度执よびフレッティング疲労強度, $K$ は定数, そして $\sigma_{\mathrm{B}}$ は 引張強さである.式(1)和よび (2)から出発して最終的に式 (3) が導か虬る(6).

$$
\sigma_{\mathrm{w}, \mathrm{c}}=\sigma_{\mathrm{w}, \mathrm{M}} \cdot \sigma_{\mathrm{B}, \mathrm{c}} / \sigma_{\mathrm{B}, \mathrm{M}}
$$

ここで $\sigma_{\mathrm{B}, \mathrm{c}}$ 複合材料の引張強さ，そして $\sigma_{\mathrm{B}, \mathrm{M}}$ は非強化材料 の引張強さである.式 $(3)$ は, B 複合材料の場合は，

$$
\sigma_{\mathrm{w}, \mathrm{c}}=1.18 \cdot \sigma_{\mathrm{w}, \mathrm{M}}
$$

そして D 複合材料の場合は，

$$
\sigma_{\mathrm{w}, \mathrm{c}}=0.92 \cdot \sigma_{\mathrm{w}, \mathrm{M}}
$$

となる.通常疲労执よびフレッティング疲労強度の式(4)特 よび式(5)火よる推定值を，Fig. 2(a)および(b)中に，B複合 材料については破線で，そしてD複合材料については一点鎖 線で示す.

$\mathrm{B}$ 複合材料の $10^{7}$ 回疲労強度の式 (4)火よる推定值は 155 $\mathrm{MPa}$ であり，測定值は推定值より䄪 $10 \mathrm{MPa}(-6 \%)$ 低く，艺 して D 複合材料の $10^{7}$ 回疲労強度の式 ( 5 ) 火よる推定值は $130 \mathrm{MPa}$ であり，測定值惟定值より約 $10 \mathrm{MPa}(8 \%)$ 高い。

一方, B 複合材料の $10^{7}$ 回フレッティング疲労強度の式 (4) による推定值は $70 \mathrm{MPa}$ であり, 測定値は推定値より約 20 $\mathrm{MPa}(28 \%)$ 高く，そしてD複合材料の $10^{7}$ 回フレッティング 疲労強度の式 $(5)$ Kよる推定值は $55 \mathrm{MPa}$ であり，測定值は 推定值上り約 $20 \mathrm{MPa}(35 \%)$ 高い，全般に通常疲労強度は測定 值と推定值は注湆同じ水準に岕るが，フレッティング疲労強度 の測定值は推定值より約30\%高い。るた D 複合材料は B 複合 材料に比べて測定值と推定值の差が大さい，々の差は通常疲労 では14\%，フレッティング疲労では7\%である。すなわち， 2024-T6 合金の $\mathrm{SiC}_{\mathrm{p}}$ による強化は通常疲労強度に対してより るフレッティング疲労強度に対して有効である。さらに両強度 の值自体は B 複合材料が D 複合材料上り高いが，複合化によ る $E$ と $\sigma_{\mathrm{B}}$ の変化の両強度への寄与分を除くと粒径 $16 \mu \mathrm{m} の$ $\mathrm{SiC}$ の方が粒径 $2 \mu \mathrm{m}$ の $\mathrm{SiC}$ 上り強度を高めるのに有効である と言壳る。

小磯ら ${ }^{(8)}$ とよると平均粒径 $6 \mu \mathrm{m}$ の $\mathrm{SiC}_{\mathrm{p}} 20 \%$ で強化した 6061-T6 合金の $10^{7}$ 回疲労強度は $180 \mathrm{MPa}$, 非強化材料の $10^{7}$ 回疲労強度は $130 \mathrm{MPa}$ であ。.前述の式(3)を適用すると， $\sigma_{\mathrm{w}, \mathrm{c}}=1.44 \sigma_{\mathrm{w}, \mathrm{M}}$ となり,この複合材料の $10^{7}$ 回疲労強度の推 定值は $187 \mathrm{MPa}$ となる。測定值と推定值はほぼ同じ水準 (-4\%)である

Bonnen ら ${ }^{(3)}$ によると平均粒径 $6.3 \mu \mathrm{m}$ の $\mathrm{SiC}_{\mathrm{p}}, 15 \%$ で強化

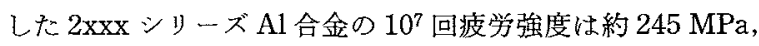
非強化材料の $10^{7}$ 回疲労強度は $240 \mathrm{MPa}$ である. 式 (3) を適 用すると， $\sigma_{\mathrm{w}, \mathrm{c}}=0.97 \sigma_{\mathrm{w}, \mathrm{M}}$ となり，この複合材料の $10^{7}$ 回疲 労強度の推定値は $233 \mathrm{MPa}$ となる。この場合も測定值と推定 值はほぼ同じ水準 $(+5 \%)$ でるる。

上記の文献(8)と(3)の結果をもとに式(3)により解析した 結果は本報の結果と同しであり, $\mathrm{SiC}_{\mathrm{p}}$ 強化 $\mathrm{Al}$ 合金基複合材料
の $10^{7}$ 回疲労強度は，ほ核複合化による $E$ およ゙ $\sigma_{\mathrm{B}}$ の変化か ら推定でさる範囲にあることを示して特り， $\mathrm{SiC}_{\mathrm{p}}$ 複合化は疲 労強度向上飞寄与していないと言光る。

\section{2. $\mathrm{SiC}_{\mathrm{p}}$ の疲学強度への影響}

$\mathrm{SiC}_{\mathrm{p}}$ 複合化による $10^{7}$ 回疲労強度の変化量は $\mathrm{SiC}_{\mathrm{p}}$ 複合化に よる $E$ 和よび $\sigma_{\mathrm{B}}$ の变化から予想される範用内で步った。

平滑試験片の高サイクル側の寿命の大部分はき裂発生寿命に 上って支配される。したがって $\mathrm{SiC}_{p}$ の疲労強度への影響は主 として疲労き裂発生寿命への影響として現れる。仮定した式 (2)の比例定数 $K$ に著しい影響を及注す材料因子は結晶粒径, 繰返し硬化・軟化挙動 ${ }^{(9)}$, 応力集中源の存在 ${ }^{(10)}$ などである。 さらに後述する $\mathrm{SiC}_{\mathrm{p}}$ 周辺に存在する縮残留応力む式 $(2)$ に 影響を及注す。これらの因子の5ち，複合化が原因で疲労強度 を低下させる働さをするのは応力集中源が導入される場合であ る.これ以外の因子は複合化に上りき裂発生寿命を遅延させ， 疲労強度を高くする。すなわち, 複合化炕りり結晶粒径は減少 し，繰返し軟化は㧕制されると考学られる(6).しかしながら， $\mathrm{SiC}_{\mathrm{p}}$ 複合化の場合, 測定值と式 $(3)$ に上る推定值にほとんよ゙ 差がないと言うことは，これらの因子が相殺されているか，あ るいはそれぞれの因子の影譬がそれ任ど大きくないことを意味 している。

\section{3. $\mathrm{SiC}_{\mathrm{p}}$ のフレッティング疲労強度への影響}

前述したよ5に $10^{7}$ 回フレッティング疲労強度の測定值は式 (3)による推定值に比べて約30\%高い.

Fig. 3 亿示した中断フレッティング疲労試験において, フレ ッティング損傷が飽和する繰返し数の全寿命に対する割合は非 強化材料では $30 \%, \mathrm{~B}$ 複合材料では $50 \%$ ，そしてD複合材料 では70\%である．き裂伝播寿命はこれらの残りの寿命の約 2 倍になるので(11)，非強化材料と B 複合材料のフレッティング 疲労寿命は活ばき裂伝播寿命である。これ《対してD複合材 料の寿命はき裂発生と伝播の両寿命が関係する.したがって, 本材料のフレッティング疲労においては $\mathrm{SiC}_{\mathrm{p}}$ がき裂伝播過程 にどのように影響するかがより重大になる。

\section{(1) $\mathrm{SiC}_{\mathrm{p}}$ の摩擦係数への影響}

フレッティング疲労に関与する応力振幅は通常疲労の応力振 幅 $\sigma_{\mathrm{a}}$ と摩摖応力振幅 $f_{\mathrm{a}}$ である. $f_{\mathrm{a}}$ は摩擦釈数 $\mu$ の関数である. $\mu$ がさい注ど疲労強度は高くなる。 $\mu$ と $\sigma_{\mathrm{a}}$ との関係を Fig. 7 K示す. $\mu$ は非強化材料と B 複合材料で注滦同じ水準 である．それに対してD複合材料の $\mu$ は約 $30 \%$ 高い。したが って，D複合材料に特ける $\mathrm{SiC}_{\mathrm{p}}$ は $\mu$ 通してフレッティング 疲労強度を低下させるよ5に作用する。

(2) $\mathrm{SiC}_{\mathrm{p}}$ のパッド接触部における主き裂発生位置への影響

フレッティング疲労に括いて最終的に破断に至るき裂がパッ ド接触部のどこで発生するか忙々の強度に直接係わる(12). 接 触面は stick region とその両側の slip regionから構成されて

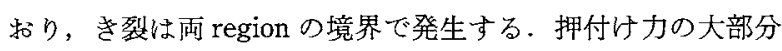
は stick regionで受ける。この regionが狭く，き裂が接触面 の中央近くから発生する場合特飞高い応力集中が生じ，フレッ ティング疲労強度の低下が見られる。笶発生位置がバッド接 触部中央であるか端部であるかの違いは高張力鋼敊よび Ti- 


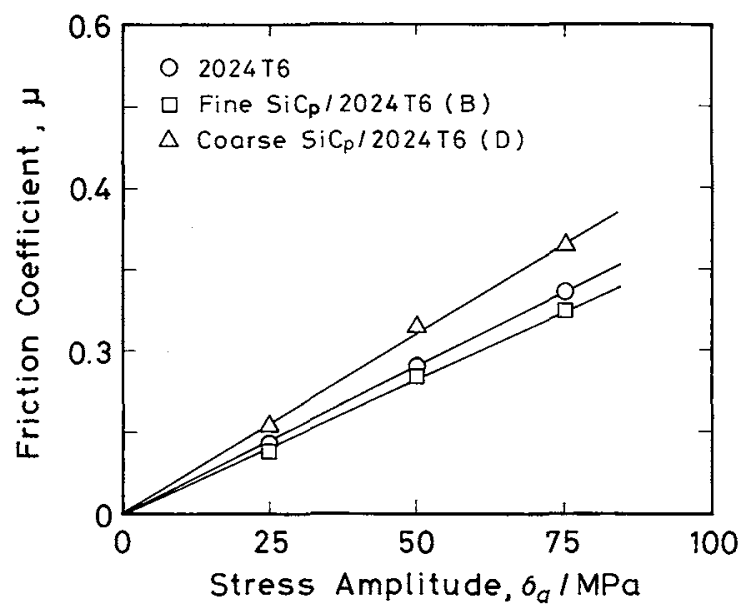

Fig. 7 Friction coefficient as a function of stress amplitude.

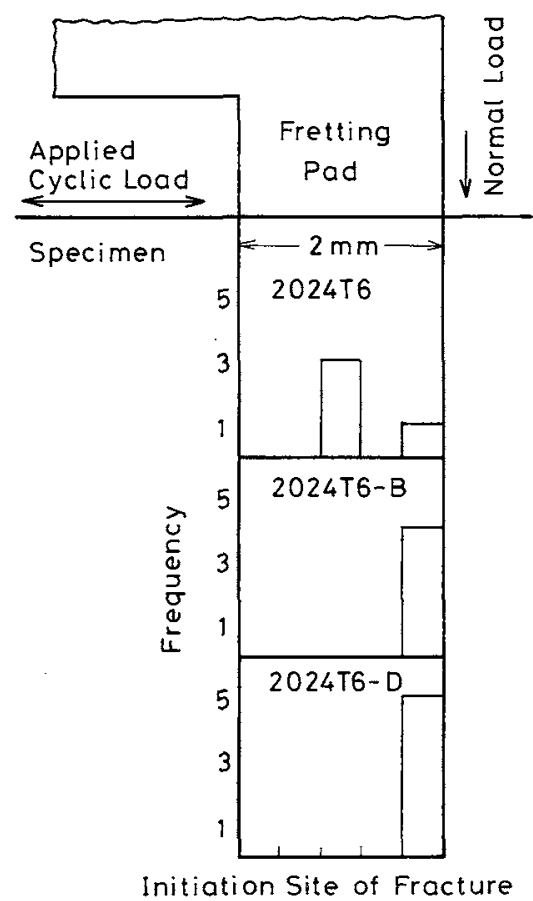

Fig. 8 Crack initiation sites of fracture in fretting fatigue specimens in Fig. 2.

$6 \mathrm{Al}-4 \mathrm{~V}$ 合金に招いて高サイクル側で 20〜30 MPa の強度差と なって現れる(13)。パッド接触部に括ける主さ裂発生位置を Fig. 8 に示す。複合材料に打いては B,Dともにき裂はすべて 接触部端部から発生していた。そそれ対して非強化材料では， 高応力振幅下の一本の試験片以外はき裂は接触部中央から発生 していた，したがって本実験条件下では， $\mathrm{SiC}_{\mathrm{p}}$ よる複合化 はパッド接触部の応力集中を分散させることにより，フレッテ ィング疲労強度を高くする効果を有する。この傾向は前報の $\mathrm{SiC}$ ゥスカー強化 7075-T6 合金の場合と同じである(6).

\section{(3) $\mathrm{SiC}_{\mathbf{p}}$ の疲労き裂伝播への影響}

Fig. 5(b) 如よびFig. 6で示したように，瘠労叔よびフレッ
ティング疲労のき裂伝播速度 $(\mathrm{d} a / \mathrm{d} N)$ が比較的遅い領域では, 破面上に $\mathrm{SiC}_{\mathrm{p}}$ は注とえど観察されない，一方， $\mathrm{d} a / \mathrm{d} N$ が速い 領域では $\mathrm{SiC}_{\mathrm{p}}$ の面積率は $25 \%$ を超える. 1 本の試験片から得 られる1対の破面で $\mathrm{SiC}_{\mathrm{p}}$ の面積率の変化に差は見られない。 このことは，き裂は最初 $\mathrm{SiC}_{\mathrm{p}}$ を避けながら進展するが，やが てき裂は $\mathrm{SiC}_{\mathrm{p}}$ とマトリックスの界面ではなく， $\mathrm{SiC}_{\mathrm{p}}$ 貫通し て進展するようになることを意味する。

以上の考察は平均粒径 $16 \mu \mathrm{m} の \mathrm{SiC}_{\mathrm{p}}$ で複合化した $\mathrm{D}$ 複合 材料の結果を基にしている. 平均粒径 $2 \mu \mathrm{m} の \mathrm{~B}$ 複合材料に 抢いては破面観察が困難であったので，Fig. 6 のよらな現象が 存在するかどうかは不明である.

$\mathrm{SiC}_{\mathrm{p}}$ 強化 $\mathrm{Al}$ 合金に衿いて，低 $\mathrm{d} a / \mathrm{d} N$ の破面上に $\mathrm{SiC}_{\mathrm{p}}$ がほ とんど観察されない例は既に報告されている(2)(3).一方，低 $\mathrm{d} a / \mathrm{d} N$ でも $\mathrm{SiC}_{\mathrm{p}}$ 体積率に相当する $\mathrm{SiC}_{\mathrm{p}}$ の面積率を示す場 合本報告されている(1)(5). $\mathrm{SiC}_{\mathrm{p}}$ の面積率と $\mathrm{SiC}_{\mathrm{p}}$ の大きされは 相関はない.文献(2)では $\mathrm{SiC}_{\mathrm{p}}$ の大きさは $3.5 \mu \mathrm{m}$ であり，そ して文献(5)では 2 4 $\mu \mathrm{m}$ である. $\mathrm{d} a / \mathrm{d} N$ は $\mathrm{SiC}_{\mathrm{p}}$ の面積率が 小さい場合に遅く，大きい場合に速い傾向がみられる(1)(5).

疲労破面上の $\mathrm{SiC}_{\mathrm{p}}$ の有無は複合材料のプロセッシングに関 係していると考られる． $\mathrm{SiC}_{\mathrm{p}}$ が疲労破面上飞汪とえど観察さ れない試料(2)(3) はそれぞれT4 お。よびT6 処理が施されてい る. 溶体化処理後時効しているが，冷間加工は加えられていな い. 本報の試料も $\mathrm{T} 6$ 処理である. 一方, $\mathrm{SiC}_{\mathrm{p}}$ の体積率に相 当する面積率を示持試料(1)(5) は $150 \sim 200^{\circ} \mathrm{C}$ て時効する前に冷 間加工が加壳られている。

疲労破面上に $\mathrm{SiC}_{\mathrm{p}}$ が抂とんど存在しない理由は次のよ5K 考劣られる.T4 扎よびT6 処理においては冷間加工を施さな いので, $\mathrm{SiC}_{\mathrm{p}}$ とマトリックス界面の接着力は大きい. $\mathrm{SiC}_{\mathrm{p}}$ と マトリックスの熱膨張係数の差は 6〜7倍める. 溶体化処理後 冷却する過程で収縮が生じるが， $\mathrm{SiC}_{\mathrm{p}}$ の熱膨張係数は小さい

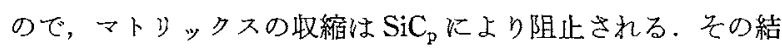
果両者の界面近くに厈縮残留応力が，そして $\mathrm{SiC}_{\mathrm{p}}$ と $\mathrm{SiC}_{\mathrm{p}}$ の中 間では引張残留応力が発生する. 老の後の時效処理は $150^{\circ} \mathrm{C}$ 前 後で行われるので残留応力は除去されるに至らない，疲労き裂 は, $\mathrm{d} a / \mathrm{d} N$ が遅く応力拡大係数が低いときは， $\mathrm{SiC}_{\mathrm{p}}$ 党避けて 引張残留応力の高い粒子間を伝播していく，しかし，応力拡大 係数が高くなり $\mathrm{d} a / \mathrm{d} N$ が速くなると，き裂先端の塑珄变形域 の中に $\mathrm{SiC}_{\mathrm{p}}$ 周辺のミク口的残留応力の不均一部は吸収され て， $\mathrm{SiC}_{\mathrm{p}}$ による沁力集中の影響が影在化する，その結果き裂 は $\mathrm{SiC}_{\mathrm{p}}$ を伝って進展するよらになる。一方，プロセッシング で冷間加工が施されると， $\mathrm{SiC}_{\mathrm{p}}$ とマトリックスの変形能の差 のために両者間の接着力は低下し， $\mathrm{SiC}_{\mathrm{p}}$ 周辺では圧縮残留応 力は発生しにくくなる。たと発生してす， $\mathrm{SiC}_{\mathrm{p}}$ の存在は空 洞と同じなので，応力集中が高くなり，き裂は $\mathrm{SiC}_{\mathrm{p}}$ とマトリ ックスの界面を伝播するよらになる。

痩労き裂が $\mathrm{SiC}_{\mathrm{p}}$ を避けて進展する場合， $\mathrm{SiC}_{\mathrm{p}}$ 周辺の圧縮残 留応力による $\mathrm{d} a / \mathrm{d} N$ の道延とデフレクションによる応力拡大 係数低下に基づく $\mathrm{d} a / \mathrm{d} N$ の遅延の相乗効果が生じる.このよ らな破面を示す試料の $\mathrm{d} a / \mathrm{d} N$ は非強化材料の $\mathrm{d} a / \mathrm{d} N$ K比べて 著しく遅くなることが期待でさる. $10^{7}$ 回フレッティング疲労 強度の測定值が式 ( 3 )火よる推定值より約 $30 \%$ 高い原因の一 つはこのき裂の $\mathrm{SiC}_{\mathrm{p}}$ 迁回にある。 
前報の $\mathrm{SiC}$ ゥスカー $\left(\mathrm{SiC}_{\mathrm{w}}\right) / 7075-\mathrm{T} 6$ 複合材料の場合 $10^{7}$ 回フレッティング疲労強度の測定值は式 (3)による推定值に 比べて約 $60 \%$ 高く(6)，これは本報の B および D 複合材料の場 合の約 2 倍に達する. $\mathrm{SiC}_{\mathrm{w}} / 7075-\mathrm{T} 6$ 複合材料拈よび7075T6 合金のフレッティング損傷が飽和する時期は遅く，全寿命 の大部分はき裂発生寿命である。また $\mathrm{SiC}_{\mathrm{w}} / 7075-\mathrm{T} 6$ 複合材料 $\mathrm{d} a / \mathrm{d} N$ 怕低応力拡大係数領域で 7075-T6 合金の $\mathrm{d} a / \mathrm{d} N$ 上 りやや速く, $\mathrm{SiC}_{\mathrm{w}}$ 複合化火よるき裂伝播抑制の効果は現孔て いない(14).

以上のことから， $\mathrm{SiC}_{\mathrm{p}}$ は疲労き裂発生抑制効果は小さいが， 疲労き裂伝播抑制には有効である，一方 $\mathrm{SiC}_{\mathrm{w}}$ はさ裂発生扣制 には有効であるが，き裂伀播抑制効果は小さいと言光る。

$\mathrm{SiC}_{\mathrm{w}}$ のき裂伝播への影響はマトリックスの種類により異な るので(14)，複合化によりフレッティング波労強度向上を目指 す場合，どのようなマトリックスにするかは重要な問題であ る.

\section{V. 結 論}

平均粒径 $2 \mu \mathrm{m}$ (B 複合材料) 打よび $16 \mu \mathrm{m}$ ( $\mathrm{D}$ 複合材料) の $\mathrm{SiC}_{\mathrm{p}}$ をそれぞれ20\%含む 2024- $\mathrm{T} 6 \mathrm{Al}$ 基複合材料を用いて，高 サイクル側の疲労強度拈よびフレッティング疲労強度に括ける 第 2 相の役割について調べた. 結果は次の通りである.

(1) $10^{7}$ 回疲労強度は, 非強化材料では $135 \mathrm{MPa}, \mathrm{B}$ 複合材

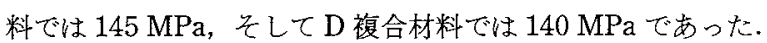

(2) $10^{7}$ 回フレッティング疲労強度は, 非強化材料では 60 $\mathrm{MPa}, \mathrm{B}$ 複合材料では $90 \mathrm{MPa}$ ，そして D 複合材料では 75 MPaであった.

（3）非強化材料执よびB 複合材料のフレッティング疲労寿 命の大部分はき裂傜寿命により支配される。D複合材料で はき裂発生寿命と伝播寿命はほぼ同じであった。

（4）フレッティング疲労に抏いて，主き裂発生個所は，非強 化材料ではパッド接触部中央，そして複合材料ではパッド接触 部端部であった。

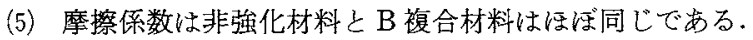
しかし，D複合材料は約 $30 \%$ 高い。

(6) 複合材料の $10^{7}$ 回疲労強度は複合化による $E$ および $\sigma_{\mathrm{B}}$ の変化を考慮して推定した強度の範囲内であり, 疲労強度に対 する複合化の効果は特に見られない。

(7) 複合村料の $10^{7}$ 回フレッティング疲労強度は複合化によ る $E$ 括よび $\sigma_{\mathrm{B}}$ の変化を考虑して推定した值より約 $30 \%$ 高い. これは，ハッド接触部の応力集中の複合化による分散，拉よび $\mathrm{SiC}_{\mathrm{p}}$ 周辺に存在する压縮残留応力に上る低応力拡大係数域で のき裂進展経路の $\mathrm{SiC}_{\mathrm{p}}$ 过回に伴う進展速度の遅延が生じるか らである。

\section{文献}

(1) Jian Ku Shang, Weikang Yu and R. O. Ritchie: Mater Sci Eng, A102(1988), 181.

(2) S. Kumai, K. Yoshida, Y. Higo and S. Nunomura: Int. J. Fatigue, 14(1992), 105

(3) J. J. Bonnen, J. E. Allison and J. W. Jones: Met. Trans. A, 22A (1991), 1007.

(4) M. Levin and B. Karlsson: Mater Sci Tech., 7(1991), 596.

(5) Y. Sugiyama and S. Suresh: Met. Trans. A. 23A(1992), 2231.

（6）角田方等，丸山典夫，中沢興三：本誌炕投稿中。

（7）中沢興三, 丸山典夫, 角田方衛, 河部義邦: 鉄之銅, 74(1988), 725 .

（8）小磯信重，三沢啓志，児玉昭太郎：材料，38(1989), 1206.

（9）角田方畤, 内山 郁：鉄之鋼，63(1977), 1700.

(10) M. Sumita, I. Uchiyama and T. Araki: Trans. ISIJ, 14(1974), 275 .

（11）角田方衛，中沢與三：「腐食損傷を受ける鉄鋼の寿命・ 余寿命 $\checkmark=ュ ア ル 」$ 日本鉄鋼拹会, 特定基礎研究会, 構 造材料の信頼性評価技術部会, (1991), 243.

（12）丸山典夫，角田方衛，中沢興三：鉄と鋼，76(1990), 262.

(13) N. Nakazawa, M. Sumita and N. Maruyama: ASTM STP $1159,(1992), 115$.

(14) K. Hirano; Fatigue 90, Proceedings of the 4th Inter Confer on Fatigue and Fatigue Thresholds, (1990), 863.

\section{訂正}

日本金属学会誌 第57巻 第10号 (1993), 1141 .

$\mathrm{Al}$ 合金基複合材料のフレッティング疲労強度に 和ける第 2 相の役割

角田方衛丸山典夫中沢興三

p.1146 左段上から 2 行目

\begin{tabular}{c|c}
\hline 正 & 誤 \\
\hline 鉄鋼材料以外の金属材料 & チタン合金 \\
\hline
\end{tabular}

